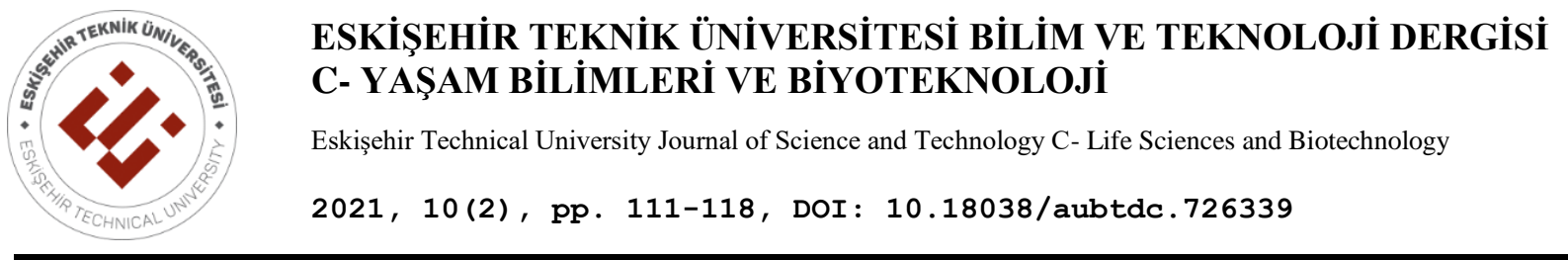

RESEARCH ARTICLE

\title{
A DETAILED STUDY OF THE MORPHOLOGY, MICROMORPHOLOGY AND FRUIT ANATOMY OF Sanicula europaea (APIACEAE)
}

\author{
Mustafa ÇELİK ${ }^{1, *}$ iD , Özlem ÇETİN ${ }^{2}$ \\ ${ }^{\mathbf{1}}$ Advanced Technology Research \& Application Center, Selçuk University, Konya, Turkey \\ ${ }^{2}$ Department of Biotechnology, Faculty of Science, Selçuk University, Konya, Turkey
}

\begin{abstract}
In this study, the morphology, palynology, fruit micromorphology and anatomy of Sanicula europaea L. were studied. The morphological description of S. europaea is expanded. Pollen morphology of the species was examined by SEM and LM, and the micromorphological characters of the fruit were also examined by SEM. Cross-sections of mature fruits were examined, and a detailed anatomical description is presented.
\end{abstract}

Keywords: Anatomy, Micromorphology, Sanicula, Umbelliferae, Turkey

\section{INTRODUCTION}

Sanicula L. (Apiaceae, Saniculoideae) is a distinctive genus of perennial woodland herbs with representatives in the north temperate zone of both the Old and New World. Sanicula comprises 47 species and its native range is Europe to SW. Siberia and N. Iran, NW. Africa. Armed with hooked bristles, a rather prominent and persistent calyx, and two persistent styles, the fruits (schizocarps) are the most characteristic feature of Sanicula, readily distinguishing it from other genera in the Apiaceae [1]. Sanicula europaea L. is widely distributed from Europe to Asia and is also found in Africa. It has been used as a medicinal plant for centuries. In traditional medicine, it is used to against diseases such as bronchial inflammation, stomach bleeding, and as a remedy for wounds [2].

The genus is represented only one species, S. europaea, in Turkey. The species is mainly distributed in northwest Anatolia and it is rare in south Anatolia [3].

In this paper, the macro- and micromorphological properties of the fruits were investigated. A detailed anatomical description of the cross sections of the mature fruits is provided. An expanded description of the species is also provided

\section{MATERIAL AND METHODS}

\subsection{Plant Material}

The specimens of Sanicula europaea were collected from its natural habitat in Karabük province, Turkey. Flora of Turkey and the East Aegean Islands was used for plant identification [4].

*Corresponding Author:mstfclk.54@gmail.com

Received: 24.04.2020 Published: 30.07.2021 


\subsection{Morphological Study}

The expanded description of Sanicula europaea is based on original description, previous literature, regional flora books $[3,5-8]$, herbarium samples, and field observations. Photos of S. europaea from digital herbariums of P, G, K, E and B were also examined.

\subsection{Micromorphological Study}

The fruits were directly mounted on the prepared stubs and coated with gold for SEM studies. Photographs were taken with a Zeiss LS-10 after coating with a Polaron SC7620 sputter coater. The pollen slides were made according to Wodehouse technique [9]. The pollen slides were examined under a light microscope and microphotographs were taken using a Nicon BX53 microscope. For SEM investigations, pollen grains were put stabs and were photographed using a Zeiss SEM. Punt et al. (1994) was followed for pollen terminology [10].

\subsection{Anatomical Study}

Mature mericarps of Sanicula europaea from Karabük population were taken from the collected specimens. Those materials were kept in $70 \%$ ethanol prior to anatomical studies. Each mericarp was rehydrated and placed in formalin-acetic acid- alcohol (1:1:8) for a minimum of $24 \mathrm{~h}$. Rehydrated materials were embedded into paraffin blocks following the traditional paraffin section method. A transverse section about 5-10 $\mu \mathrm{m}$ thick was cut using a Thermo microtome and stained with safranin solution. Micrographs were taken using a Nikon light microscope.

\section{RESULTS}

\subsection{Description}

Sanicula europaea L., Sp. Pl. 1: 235 (1753). (Figures 1, 2, 3, 4).

Erect, glabrous, perennial, usually one-stemmed, rarely 2-3, 15-80 (-120) cm tall. Rootstock stout, short and dark brown. Stem simple, $1.5-3 \mathrm{~mm}$ in diameter at base, \pm sulcate, solid, usually branching from the upper part. Basal leaves 5-15(-30), long petiolate; lamina cordate-orbicular in outline, 2-9 $\times 2.5-14 \mathrm{~cm}$, palmately 3-5(-7) partite, segments cuneate-obovate, entire or lobed, the median segment usually larger and free nearly to the base, the lateral segments connate to c. 1/3 at base, margin irregularly crenateserrate, the teeth ending in a short bristle; petioles much longer than the lamina, 3-21(-25) cm long, basal sheaths small. Cauline leaves few, short petiolate or subsessile, 2-3 ternate with ovate to lanceolate, usually lobed or toothed segments. Inflorescence mostly terminal, 2-4 furcate, the middle usually ending a simple umbel, the others ending a compound umbel. Umbels (2-)3 rayed, 1.5-4 cm in diameter; rays spreading, 5-32 × 0.3-0.6 mm, subequal. Bracts (2)3-5(-10), 1-3 × 0.3-0.8 mm, herbaceous, linear, entire or sometimes with a few teeth, acute to acuminate at apex. Umbellules with 2-3 inner hermaphrodite flowers, and numerous outer male flowers; hermaphrodite flowers sessile, male flowers short pedicellate. Bracteoles 4-8, 0.8-1.5(-2.5) $\times$ 0.2-0.5 mm, lanceolate-ovate, herbaceous, entire. Sepals distinct, subulate, $0.5-1 \mathrm{~mm}$ long, persistent in fruit. Petals white or pinkish, oblong to ovate, inflexed, 1-2 (-4.5) mm long. Stamens exceeding petals; filaments yellowish, 2-3(-4.5) mm long; anthers, yellowish to yellow, sub-globular, c. $0.6-0.3 \mathrm{~mm}$, dorsally inserted. Fruit ovate to orbicular, densely covered with hooked bristles, slightly compressed laterally, (2.5-) 3-5 $\times 2-3 \mathrm{~mm}$; ribs inconspicuous, stylopodium flattened; style 2.3-3.5 mm long, slender, recurved; carpophore absent; vallecular vitta 1 , commissural vittae 2 . 


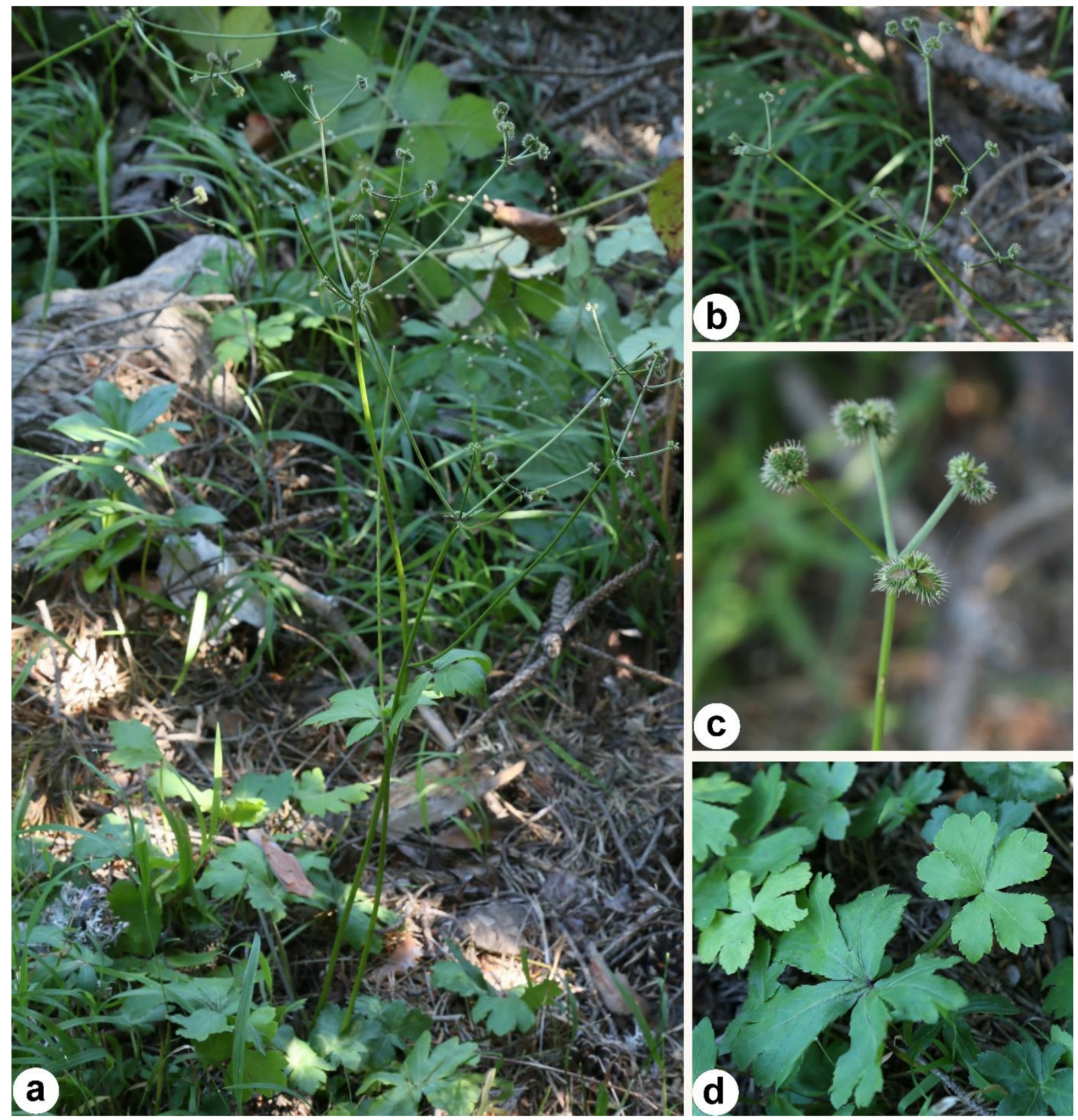

Figure 1. Sanicula europaea: a- habit, b- closer view of the upper part, c- fruiting umbel, c- closer view of the basal leaves.

\section{Phenology, ecology and habitat of the species}

Sanicula europaea is found in shady places, shaded roadsides, hedge banks, moist wooded riverbanks, deciduous woodland and rarely mixed and coniferous forest. Sanicula europaea is widespread in North Anatolia and it is rare in South Anatolia. The altitudinal distribution of this species varies from sea level to $2200 \mathrm{~m}$. The flowering time is between May and August in Turkey.

\subsection{Anatomical Results}

The fruit of Sanicula europaea is elliptical in transverse section. Mericarps are nearly semi-circular. Ribs are weakly developed and mostly inconspicuous. The exocarp is single layered and is interrupted 
towards the middle of the commissural surface. It consists of rectangular or square-like cells. Their outer walls are covered by a thin cuticle layer. The mesocarp is composed of multi-layered parenchyma cells, which are thin-walled and irregular polygonal in shape. Vascular bundles located under the ribs are surrounded by mesocarp cells. Vittae are relatively small and oblong-elliptic or nearly orbicular. They are lined by thin-walled epithelial cells. There is one vallecular vitta and two commissural vittae. The endocarp is thin and single layered. Endosperm cells are irregular polygonal shaped with granular contents (Figure 2).

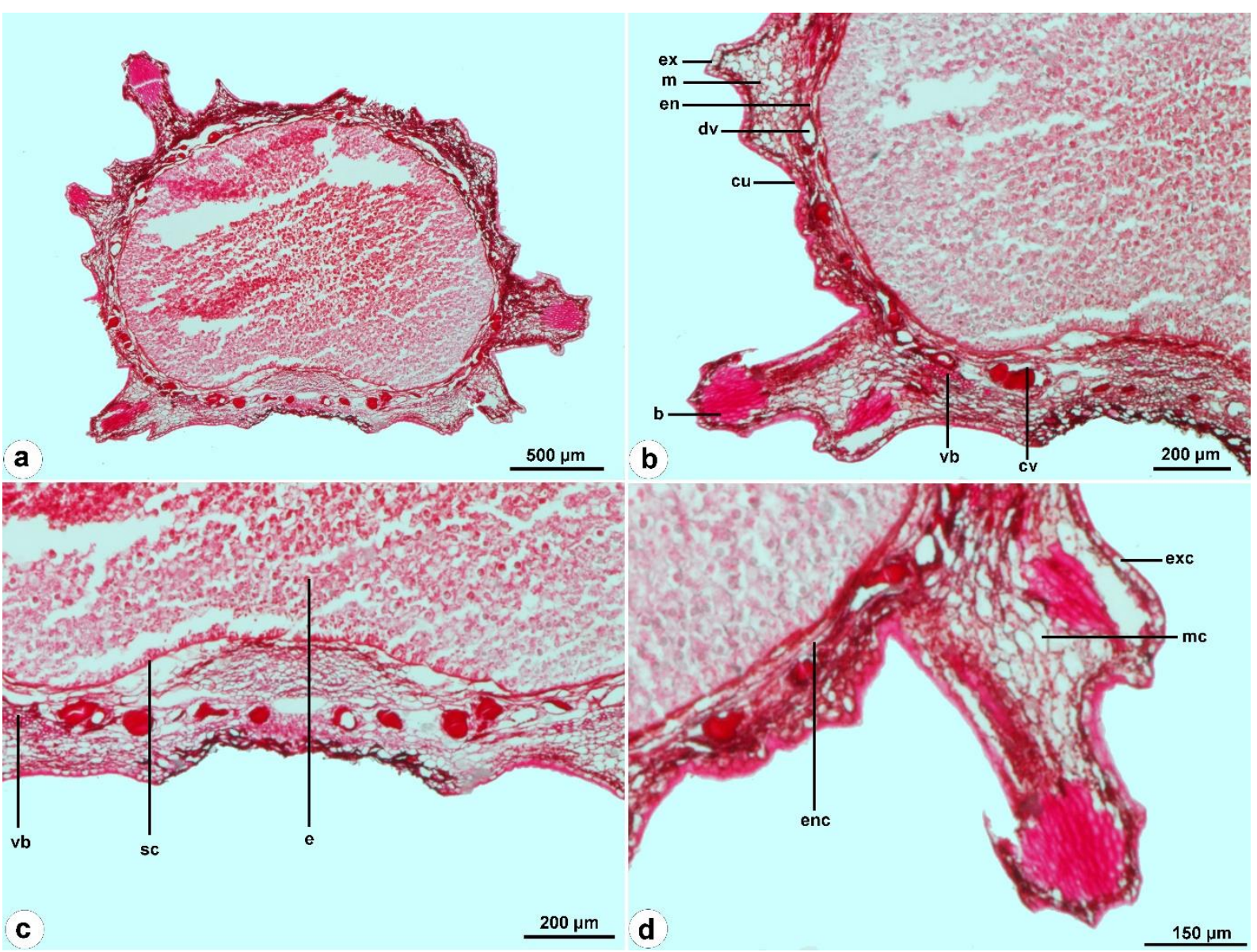

Figure 2. Photomicrograph of mericarp cross section of the Sanicula europaea: a- general view, b- lateral view, c- commissural view, d- detailed view. b- bristle, e- endosperm, en- endocarp, enc, endocarp cell, exexocarp, exc- exocarp cell, cu- cuticle, cv- commissural vitta, dv- dorsal vitta, m- mesocarp, mcmesocarp cell, sc- seed coat, vb- vascular bundle.

\subsection{Micromorphological Results}

\subsubsection{Pollen properties}

The pollen grains of Sanicula europaea are monad, isopolar, radially symmetric and tricolporate. The polar axis (P) of pollen grains ranges from 37.67 to $49.06 \mu \mathrm{m}$ and their equatorial axis (E) ranges from 19.91 to $21.85 \mu \mathrm{m}$. The ratio of the length of the polar axis to the equatorial diameter (P/E) averaged $2.75 \pm 0.30$ making the pollen grain shape perprolate. In polar view, the pollen grains are nearly circular. In a equatorial view, the grains are narrowly oblong with slightly equatorial constriction and obtuse polar caps. Colpus almost extend to the poles. The pore area is slightly protruding and is located in the middle of colpus. The sculpturing pattern is irregularly rugulate-perforate (Figure 3). 


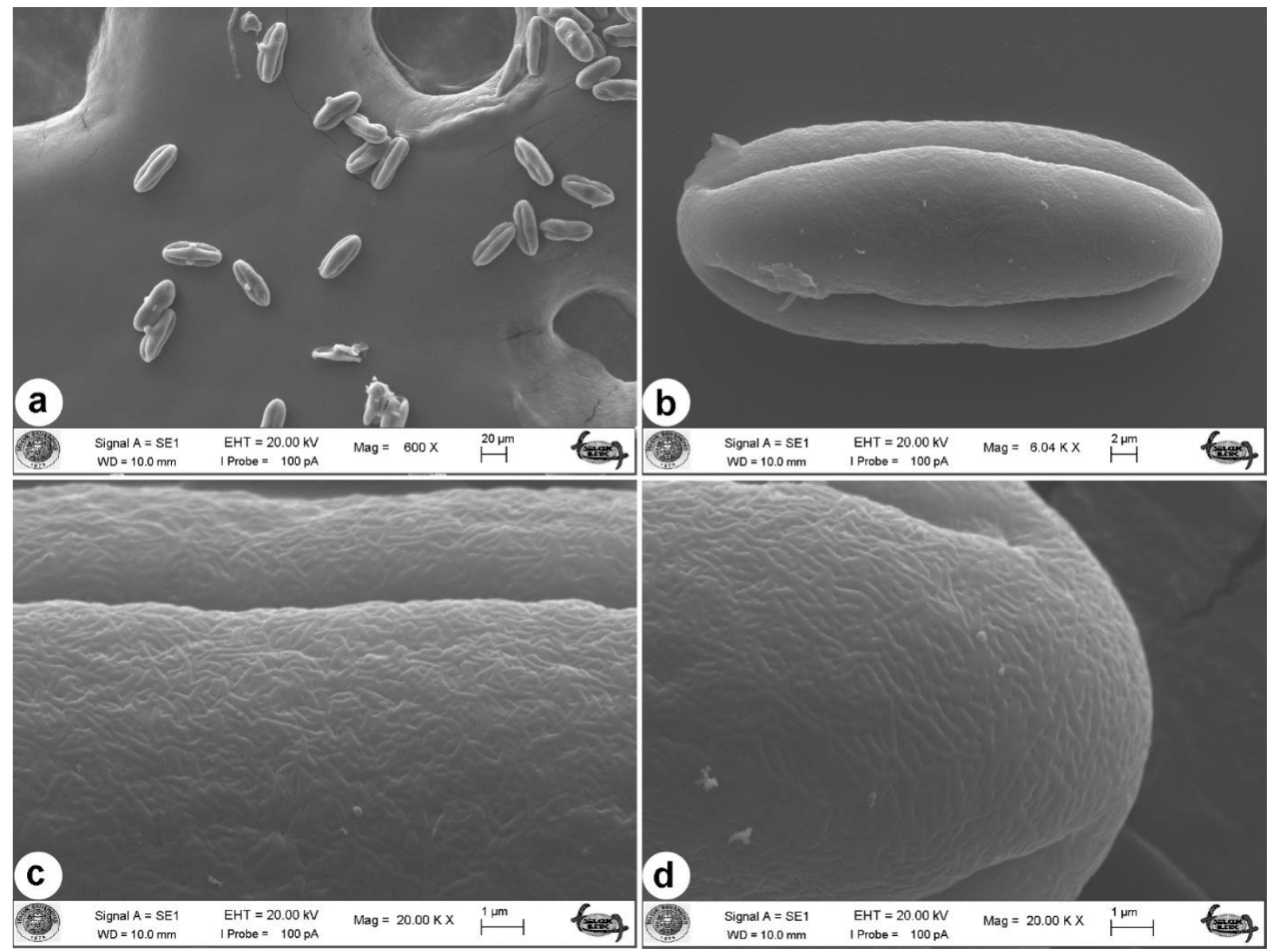

Figure 3. Micrograph of pollen grains of the Sanicula europaea: a- pollen grains, b- general view of the pollen grain, c- equatorial view of the pollen grain d- polar view of the pollen grain.

\subsubsection{Mericarp surface properties}

The ribs of Sanicula europaea are mostly indistinct. The surface of fruit is covered with multicellular hooked spines. While the spines are smooth in general view, slightly striated in detailed view. The mericarp surface is wrinkled in general view. Cell boundaries are generally conspicuous, sometimes inconspicuous. Mostly, these cells are irregularly polygonal and their anticlinal boundaries are slightly raised and straight. Outer periclinal walls are tabular with a smooth surface (Figure4). 


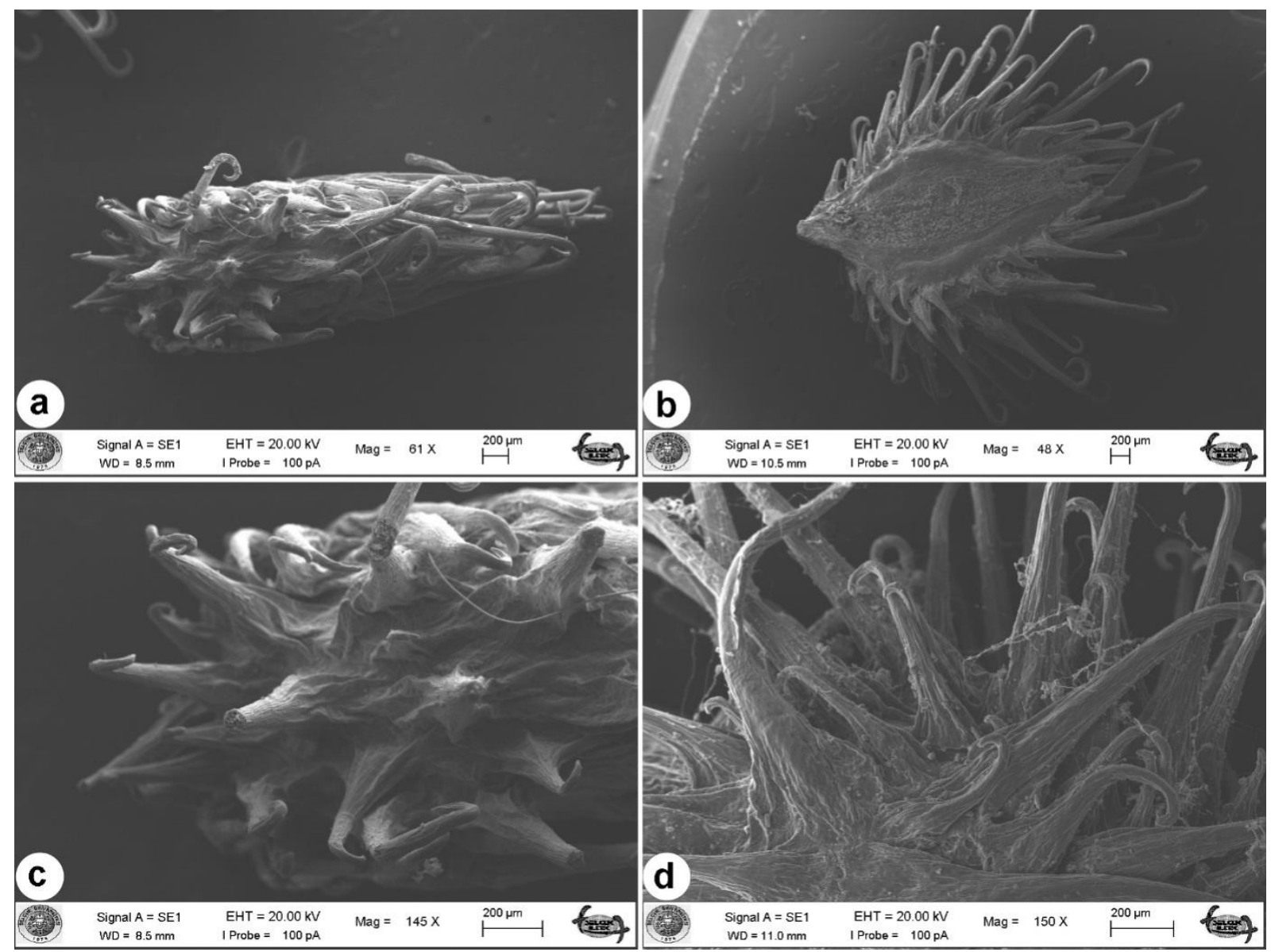

Figure 4. SEM aspect of mericarp surface of the Sanicula europaea: a- general view of the dorsal side, b- general view of the commissural side, c- close view of the dorsal side, $d$ - mericarp surface.

\section{DISCUSSION}

The present study sought to provide useful information on the morphology, palynology, fruit anatomy and micromorphology of Sanicula europaeae.

The family Apiaceae is a stenopalynous family [11]. Palynological characteristics of the Apiaceae family have been studied by many different researchers. Perveen and Qaiser (2006) studied pollen grains of 50 species representing 27 genera of the family Apiaceae from Pakistan, and they recognized three distinct pollen types- Bupleurum gilessii-type, Pleurospermum hookeri-type, and Trachyspermum ammi-type, on the basis of the exine pattern. Species of Trachyspermum ammi-type, which include Sanicula elata, are characterized by 3-colporate and 3-zonocolporate pollen type, striate tectum and perprolate to prolate shape [12]. According to our study, the pollen of Sanicula europaea is tricolporate and perprolate, the exine ornamentation is rugulate, perforate.

Fruit micromorphology of 65 species belonging to Apiaceae family was studied by Ostroumova (2018). It is reported that exozoochoric fruits of Sanicula chinensis and S. rubriflora are covered with multicellular hooked spines, which are smooth in Sanicula [13]. According to our study, the fruit of Sanicula europaea is also covered with smooth hooked spines.

Micromorphological features of the pericarp surface of 15 Sanicula species were studied by Zhi-Xiang et al. (2019). Ornamentation type was observed as undulate in S. canadensis, S. rubriflora, S. rugulosa; 
as reticular in S. chinensis; as stripes in S. trifoliata, S. serrata, S. wenchuanensis, S. menziesii, S. marilandica, S. elata, S. coerulescens; as granular in S. nevadensis; as camber in S. odorata. The cell shape of $S$. canadensis, $S$. chinensis, $S$. menziesii, S. nevadensis and S. rubriflora is tetragon-hexagon; while the cell shape of S. laciniata, S. marilandica, S. odorata, and S. trifoliata is pentagon-hexagon. The cell shape of $S$. elata, $S$. giraldii, $S$. rugulosa, and $S$. serrata are invisibly outlined [14].

Liu et al. (2012) emphasized the phylogenetic significance of carpophores in Apiaceae. They reported that two mericarps connected with parenchyma cells, and no vascular tissue is found between mericarps in Saniculeae, except the genus Alepidea and Arctopus [15].

The anatomical study of aerial and underground organs of Sanicula europaea was carried out by Grytsyk et al. (2019). According to Grytsyk et al. (2019), the upper epidermis cells are parenchymal with undulate-emarginate thin membranes; the lower epidermis cells have winding membranes, and the stomata are found mostly on the underside of leaves and are anisocytic [16]. Comparative anatomical study of leaves, stems, and roots of Petagnaea gussonei, Lereschia thomasii, and S. europaea was conducted by Colombo et al. (1997) [17].

Fruit characteristics of Sanicula coerulescens, S. rubriflora, S. lamelligera, and S. europaea were studied by Liu et al. (2003). Fruit shape of $S$. lamelligera and $S$. europaea are elliptic, whereas $S$. coerulescens and $S$. rubriflora are oval. Commissural vittae and carpophores are also absent in these species [18].

The detailed description of $S$. europaea is given in this study. Our findings were compared with the description in Flora of Turkey and the East Aegean Islands and differences are presented: stem 15-120 $\mathrm{cm}$ (not $60 \mathrm{~cm}$ ), basal leaves $2.5-14 \mathrm{~cm}$ wide (not 3-12 cm), bracteoles 4-8 (not 6-8), fruit (2.5-) 3-5 mm long (not $2.5 \mathrm{~mm}$ ). Some additional morphological characteristics of Sanicula europaea are also given in description.

As a conclusion, the morphological, palynological, micromorphological and anatomical characteristics of the species are reviewed. We expect that our study will shed light on further studies on the genus Sanicula.

\section{CONFLICT OF INTEREST}

The author stated that there are no conflicts of interest regarding the publication of this article.

\section{REFERENCES}

[1] Pryerk M, Phillippel RA. synopsis of the genus Sanicula (Apiaceae) in eastern Canada. Can J Bot, 1989; 67: 694-707.

[2] Hiller K. Sanicula europaea L.-Sanikel. Z Phytother, 2005; 26(5): 251-254.

[3] Hedge IC, Lamond JM. 1972. Sanicula. In: Davis PH, editor. Flora of Turkey and the East Aegean Island. 4th volume. Edinburgh, UK: Edinburgh University Press, 1972. pp. 289-290.

[4] Davis PH. Umbelliferae. Flora of Turkey and the East Aegean Islands. 4th volume. Edinburgh, UK: Edinburgh University Press, 1972. 
[5] Vargas P. Sanicula L. In Nieto FG, Jury SL, Herrero A, editors. Flora Iberica. Plantas vasculares de la Península Ibérica e Islas Baleares. 10th volume. Madrid, Spain: Real Jardín Botánico, CSIC, 2003; pp. 30-32.

[6] Tutin TG. Sanicula L. In: Tutin TG, Heywood VH, Burges NA, Moore DM, Valentine DH, Walters SM, Webb DA, editors. Flora Europaea. 2nd volume. Cambridge, UK: Cambridge University Press, 1968. p. 320.

[7] Schlosser von Klekowski JC, Farkas-Vukotinovis L. Flora Croatica. Zagrabiae, Croatia: Apud Fr. Zupan, 1869.

[8] Dietrich AG. Flora Regni Borussici. 8th volume. Berlin, Germany: Verlag von Ludwig Ochmigke, 1840.

[9] Wodehouse RP. Pollen Grains. New York, USA: Mc Graw Hill, 1935.

[10] Punt W, Blackmore S, Nilsson S, Thomas A. Glossary of Pollen and Spore Terminology. Utrecht, Netherlands: LPPFoundation, 1994.

[11] Erdtman G. Pollen morphology and plant taxonomy Angiosperms: An Introduction to Palynology. Stockholm, Sweden: Almqvist and Wiksell, 1952.

[12] Perveen A, Qaiser M. Pollen Flora of Pakistan-XLVIII. Umbelliferae. Pak J Bot, 2006; 38(1): 114.

[13] Ostroumova T. Fruit micromorphology in the Umbelliferae of the Russian Far East. Botanica Pacifica, 2018; 7(1): 41-49.

[14] Zhi-Xiang C, Xue-Ying Y, Downie S, Qi-Zhi W. Fruit features of 15 species of Sanicula (Apiaceae) and their taxonomic significance. Plant Sci J, 2019; 37(1): 1-9.

[15] Liu M, Plunkett GM, Van Wyk BE, Tilney PM, Lowry PP. The phylogenetic significance of the carpophore in Apiaceae. Ann Bot, 2012; 110: 1531-1543.

[16] Grytsyk LM, Legin NI, Grytsyk AR, Melnyk MV. Morphological and anatomical research of Sanicula europeae L. Farmatsevtychnyi Zhurnal, 2019; 4: 53-58.

[17] Colombo P, Melati MR, Scialabba A, Raimondo FM. Comparative anatomy and development in Petagnaea, Lereschia and Sanicula (Umbelliferae). Bocconea,1997; 5: 613-618.

[18] Liu M, Van Wyk BE, Tilney PM. The taxonomic value of fruit structure in the subfamily Saniculoideae and related African genera (Apiaceae). Taxon, 2003; 52: 261-270. 